\title{
MILITARIZATION OF PUBLIC SECURITY AND VIOLATION OF HUMAN RIGHTS IN MEXICO (2000-2020)
}

\author{
PIERRE GAUSSENS ${ }^{1}$ \\ CAROLINA JASSO GONZÁLEZ
}

\begin{abstract}
This article analyses the militarization of public security in Mexico from a human rights perspective to observe the main effects of this policy at the national level in the last twenty years (2000-2020). The methodology used is mixed, combining a quantitative and a qualitative approach. The investigation shows that militarization, far from fighting crime, contributes to general growth in violence and human rights violations. Its main result is increasing lethality of security institutions in the use of public force, indicating that an important part of what had been presented as combats with organized crime, are instead extrajudicial executions. This harsh reality is illustrated with a case study based on the events that occurred in Tlatlaya in 2014.
\end{abstract}

Keywords: militarization; human rights; security; violence; lethality; executions; Mexico.

Summary: 1. Introduction. 2. About militarization. 3. Militarization of public SeCurity in meXico. 4. Violence and violation of human Rights. 5. Lethality in the use of public force. 6. Extrajudicial eXecutions: The tLatLaya Case. 7. Conclusion.

\section{INTRODUCTION}

In Mexico, human rights face several structural problems because of the conjunction of different factors. Among them, it is possible to distinguish institutional opacity, widespread impunity, saturation of the judicial system, increase in crime and other dynamics of violence, militarization of public security, and corruption, which allows cooperation between official agents and criminals. In this context, human rights violations acquire new features and are expressed in increasingly complex patterns. Paradoxically, as a result of the Constitutional Reform of 2011, the institutional discourse around the protection of human rights and the constitutional mandate to promote, respect and guarantee them has not only been diminished, but also made impossible in the face of the increase in cases of serious human rights violations committed by State agents.

Does the deployment of the Armed Forces in public security tasks inevitably favor the development of conditions for the occurrence of human rights violations? Is it possible to respect and guarantee human rights in a militarized context? Based on these questions, the aim of the article is to demonstrate the incompatibility between this militaristic paradigm and the defense and protection of human rights, through an analysis and dialogue with the existing literature, including the available empirical evidence.

\footnotetext{
${ }^{1}$ Professor at The College of Mexico (pgaussens@colmex.mx).

${ }^{2}$ Masters student at The College of Mexico (cjasso@colmex.mx).
} 
The results presented here are the product of a research work on the effects of the militarization of public security in the field of human rights, at the national level in the last twenty years (2000-2020). Therefore, this article starts from a perspective of historical sociology that allows us to follow the evolution and trace the process of development of the phenomenon, even considering the previous decades, particularly the nineties, essential to understand the genesis of militarization as politics. The methodology used is mixed and documentary, that is, it is based on both descriptive statistical elements and qualitative tools, through research work that allowed reviewing various sources of information: results of academic research, reports and recommendations on human rights, legal documents - Such as laws, budgets, and judicial decisions in cases of human rights violations - as well as official statements and press articles. Finally, in order to illustrate the results of the descriptive statistics, we have used the methodology of the case study to delve into a case whose singularity is representative of the problem under investigation.

In addition to the introduction and conclusions, the article is divided into five sections. The first develops a theoretical discussion to propose a definition of militarization that allows a better understanding of the phenomenon. In the second section, the historical process of militarization in Mexico is analyzed in relation to institutional changes and the evolution of public spending. The third section studies the increase in violence and human rights violations in the context of this militarization, while the fourth takes the lethality of the public force as the unit of analysis. Finally, the last section illustrates the problem of extrajudicial executions by reviewing the Tlatlaya case, which is emblematic of the human rights crisis in Mexico today.

\section{About militarization}

Several problems arise when talking about militarization. As Eissa and Gastaldi (2014) note, this situation has not generated an extensive discussion in the LatinAmerican academic field. Its meaning is often taken for granted or, on the contrary, its use is avoided due to the perception of some ideological connotation which is inseparable from this same lack of conceptualization. In addition, the predominant quantitative perspective, articulated around international indexes, tends to reduce the phenomenon to its measurement, by focusing on budgets, numbers of troops and weapons. Although these numbers are important to get an idea about military spending, they do not account for the qualitative processes that accompany the exercise of these budgets. As Morales and Pérez Ricart (2014a, p. 10) warn, models constructed from this perspective are "easy to operationalize, but restrictive and incapable of portraying the dimensions and dynamics of militarization that go beyond the formal borders of military institutions."

Some works have theorized the concept of militarization, such as those of Hathazy (2016), Hall and Coyne (2013), as well as, in the Mexican case, those of Alvarado and Zaverucha (2010) or Morales and Pérez Ricart (2014a, 2014b). Likewise, the militarization processes that have taken place during the last two decades in Mexico, Latin America and other countries have opened new debates regarding the use of public force, the increase in institutional violence, and the violation of human rights. These discussions have focused in particular on the effects that military intervention has on police corporations, the judicial 
system, the penitentiary system, and other civil institutions (Kraska, 2007; Jobard, 2008; Zaverucha, 2008; Moloeznik, 2012; Hathazy, 2016; Pion-Berlin, 2017; Lawson, 2018, 2019).

At the current state of these debates, there is no agreed upon definition of militarization, but it is possible to identify several complementary analytical proposals. The first of these, formulated by Hall and Coyne (2013), can serve as a starting point since it introduces a distinction between direct and indirect militarization: while the first occurs when the Armed Forces are deployed for the purpose of controlling the internal order, blurring the line that separates police and military functions, the second refers to the adoption by police corps of characteristics from the Armed Forces, with the incorporation of military strategies, equipment and weapons, that is, when "police begin to proactively seek criminals" (Hall; Coyne, 2013, p. 487). The main virtue of the indirect militarization approach is to understand the problem in a heterogeneous and complex way, by expanding it beyond the strict military sphere. The civic-military division becomes more complex when considering the participation of civil and political agents, together with the military, within the processes of militarization.

Morales and Pérez Ricart (2014b, p. 12) return to this approach for the Mexican case, but with criticism, because "the analytical separation between direct and indirect forms does not explain whether or how the latter are related to the former. It also fails to explain the consequences of the phenomenon on the military institutions themselves." Therefore, both researchers understand militarization as the result of a dual, interdependent process in which, on the one hand, military institutions become central in the definition of security policies, acquiring a hegemonic position in relation to the structuring of State violence, and, on the other, in which civil institutions adopt military logics for their operation. The dependent relationship established between civil and military institutions leads to isomorphic processes of mutual similarity. By establishing the Armed Forces as a hegemonic actor, this conceptualization underscores the asymmetric nature of the relations that unite the military and civilians in the field of security, in which the former tends to occupy privileged positions to the detriment of the latter. However-as Kraska (2007) also warns - the asymmetry that characterizes these relationships is not one-way, so it is necessary to pay attention not only to the processes of militarization inside the police, but also, conversely, to the policing of the Armed Forces.

Following this line of argument, another proposal is advanced by Hathazy (2016), who distinguishes four dimensions in militarization: 1) that of police jurisdiction, when it is delegated to the military, in away equivalent to the direct form of militarization; 2) the organic one, which distributes the police functions between civil and military organisms; 3 ) the institutional one, when the civil organisms adopt operating logics typical of the Armed Forces as an indirect form of militarization; and, 4) the discursive one, with the production of official war rhetoric. These four dimensions operate interdependently. Through them, Hathazy seeks to point out the importance of the interests at stake in the field of security, whose stakeholders (political, bureaucratic and economic agents) fight over the definition of a legitimate policy, with its corresponding strategies and budgets. Thus, this analytical approach allows for a dynamic understanding of how, in historical moments, security 
institutions manifest "objective relationships based on their size, resources, and prestige" (Hathazy, 2016, p. 186).

On the other hand, the definitions of Kraska (2007) and Lawson (2019) are useful in emphasizing the use of force. According to the former, militarization is understood as an extension of militarism, that is, as a tendency to privilege the force or threat of violence as the most effective means of solving social problems. In other words, militarization is the application of the elements that make up the military model to a particular organization or situation (Kraska, 2007). In this way, police militarization represents the process by which the police adopt the material, cultural, organizational and operational principles of military institutions. Finally, Lawson (2019) adds that, as a result of militarization, police officers tend to think that exercising force is the most effective means of resolving social conflicts. Consequently, militarized police forces not only tend to perceive protection and prevention functions as secondary, given the priority task of fighting crime, but to prefer the use of force, which translates into a propensity for violence.

Based on some elements expressed in these three proposals, we understand militarization as the general process of reconfiguring State power through the delegation of the use of its force in favor of military institutions, whose role thus occupies a central position in the field of security, and whose operating logics are adopted by civil institutions, in particular by police and judicial institutions. In this way, exchanges between the military and civil security organisms are characterized by a growing asymmetry. In the struggle between both sectors for control over public security functions, militarization expresses the domination of the former over the latter. The following processes are part of its main dimensions - policy, legal and organizational (Table 1):

Table 1. Dimensions and processes of militarization

\begin{tabular}{|c|l|}
\hline DIMENSION & \multicolumn{1}{c|}{ PROCESSES } \\
\hline \multirow{4}{*}{ Policy } & Involvement of the Armed Forces in internal security \\
\cline { 2 - 3 } & Submission of civil institutions to the military \\
\cline { 2 - 3 } & Military control over key budget positions \\
\cline { 2 - 3 } & $\begin{array}{l}\text { Implementation of unified commands, joint operations and other spaces for } \\
\text { civil-military coordination }\end{array}$ \\
\cline { 2 - 3 } & Production of an official war discourse \\
\hline \multirow{4}{*}{ Legal } & $\begin{array}{l}\text { Adoption of a legislation and jurisprudence that justify military } \\
\text { interventionism }\end{array}$ \\
\cline { 2 - 3 } & Consolidation of the military jurisdiction and its autonomy over civil justice \\
\hline \multirow{5}{*}{ Organizational } & Transfer of military personnel and technology to civil institutions \\
\cline { 2 - 3 } & $\begin{array}{l}\text { Appointment of military personnel (active or retired) to command and high- } \\
\text { level positions inside civil institutions }\end{array}$ \\
\cline { 2 - 3 } & $\begin{array}{l}\text { Imposition of military logics in the institutional operation of civil organisms } \\
\text { and application of military doctrine to the police forces }\end{array}$ \\
\hline
\end{tabular}

Source: Elaborated by the authors 
Finally, considering the different analytical proposals outlined, the problem of militarization requires a multidimensional theoretical treatment that makes it possible to account for the complexity involved in turning or returning the Armed Forces to perform public security tasks, its effects on other institutions, and its social impacts. To sum up, it is necessary adopting a relational and procedural perspective focused on showing the political, legal, organizational, and contextual processes that interact and are mobilized in the face of the military's involvement in internal security.

\section{Militarization OF PUbliC SECURITY IN MEXICO}

Over the past decades, the Armed Forces have become a central actor in security policies in Mexico. It is difficult to ignore the speed at which military prerogatives were expanded, which forces us not only to reflect on its effects, but also on the factors that favored its deployment. The reformulation of the Armed Forces responsibilities occurred in a context marked by the growth of crime rates, the perception of insecurity, and the emergence of debates around the need to implement police and military reforms (Dammert, 2005; Bailey and Dammert, 2006; Dammert and Bailey, 2015), in which security became a central issue on the political agenda throughout Latin America (Fondevila and Navarrete, 2013). Today, there is a consensus in the academic literature regarding the implementation of a security policy under a militaristic paradigm in Mexico. The discussions suggest that this scheme is associated with the increase in violence and human rights violations, as a general situation that poses serious challenges for democratic governance (Bagley, 1992; López-Menéndez, 2000; Artz, 2003; Barrón, 2003; Moloeznik, 2007; Camp, 2010; Piñeyro, 2010; Alvarado and Zaverucha, 2010; Moloeznik and Suárez de Garay, 2012; Sotomayor, 2013; Silva and Padilla, 2019).

Moreover, it is necessary to remember that the militarization of public security in Mexico is not the result of spontaneous generation. On the contrary, there is a series of antecedents in the 20th century. The first of these is the early participation of the Army in the fight against drugs, through the eradication of illicit crops, which dates to the late 1930s in the north of the country (Astorga, 2007, p. 57). The second refers to the counterinsurgency campaigns carried out in the 1960s and 1970s, in the context of the so-called Dirty War (Herrera and Cedillo, 2012), and which were updated two decades later in the face of the Zapatista uprising (Sierra Guzmán, 2007). In this sense, from the 1990s onwards, the (re) militarization of public security refers to an evolution in the Army's trajectory in which "it assumed a new role and began a process of organizational, technical, and budgetary renewal, as well as in equipment and internal security planning" (Alvarado and Zaverucha, 2010, p. 254).

Indeed, as a result of the Zapatista uprising in Chiapas, the militarization of public security became State policy under the auspices of the United States' foreign policy, after signing the North American Free Trade Agreement. Thus, "the reasons for this shift seem to have responded more to an alignment with the American-inspired vision than to selfconviction" (Astorga, 2007, p. 30). In general terms, Mexican military institutions went through internal reorganization processes based on the model and with the direct support of the US Army. Military budgets were increased, while contingents grew both in number 
and quality, through the multiplication of special forces corps and the concomitant purchase of new armaments. Likewise, the geographical distribution of the Army in the national territory was reviewed to concentrate its forces.

Two big moments of institutional and political changes have been significant in this evolution. The first turning point was the creation in 1995 of the National Public Security System, an "organizational hybrid"- an expression by Alvarado and Zaverucha (2010) - that integrates the Secretariat of National Defense (SEDENA) and the Secretariat of the Navy (SEMAR) within it, together with civil organisms. This integration allowed for the incorporation of the military in key instances for the design of security policy, such as the National Council for Public Security and the Attorney General's Office (PGR). This incorporation was supported the following year by a controversial Supreme Court ruling. ${ }^{3}$ At the same time, a substitution policy was initiated to replace police officers with military personnel at medium and high command levels, both in instances of public security and justice - including preventive and judicial police tasks - covering 29 of the country's 32 states (López-Ménendez, 2000). It was also during Ernesto Zedillo's presidency that the Mixed Operations Bases (BOM) were created between the Army and police corps. Finally, in 1999, the Federal Police was born, by integrating troops from the Military Police, as a new corporation that is part of a vast project of unified police command.

The second critical moment occurred during Felipe Calderón's government (20062012), with an official discourse based, on the one hand, on the narrative of a dispute for territorial control between organized crime groups (the so-called "cartels") and, on the other hand, on a position that sought to highlight the weaknesses of civil security institutions and their inability to maintain internal order. Linked to military semantics, this official discourse involved not only dealing with crime, but also recovering those territories supposedly usurped by the "enemy" (Astorga, 2015). In this way, the militaristic paradigm was deepened even further after signing the Mérida Initiative. It was repeated that there was no other alternative than to deploy the Armed Forces, presented as the only institution with enough professionalism, discipline, and technical capacity to contain criminal violence. This "militaristic explanation" (Piñeyro, 2010) was based on two key assumptions: The Armed Forces' lower corruption levels and greater effectiveness against crime compared to police and judicial institutions. ${ }^{4}$

\footnotetext{
${ }^{3}$ In the ruling about unconstitutionality action $1 / 96$, the Supreme Court affirmed, in a highly contradictory way, that "the functions that have an exact connection with military discipline, referred to in article 129 of the Constitution, go beyond the internal tasks in military life [...] within which it is found to assist civil authorities with the use of force at their disposal in tasks related directly or indirectly to public security" (SCJN, 1996, p. 214). This interpretation does not cease to constitute a flagrant violation of the article invoked.

${ }^{4}$ This argument needs to be problematized in at least two dimensions. In the first instance, it is undeniable that a significant proportion of state and local police institutions were unable to carry out their tasks, as a result of a lack of budget and professionalization, which is partly explained by the disputes over "material and symbolic rewards" (Hathazy, 2016, p. 82) between civil and military institutions, but also because of the depth of corruption that unites police and criminals in Mexico. Rather than a capture of the police by criminal interests, this situation responds to a more complex and profound logic of cooperation, in which the border between law and crime is blurred, such as have evidenced the recent cases of Edgar Veytia and Genera García Luna. In this context, it was implausible to delegate the task of containing crime to local
} 


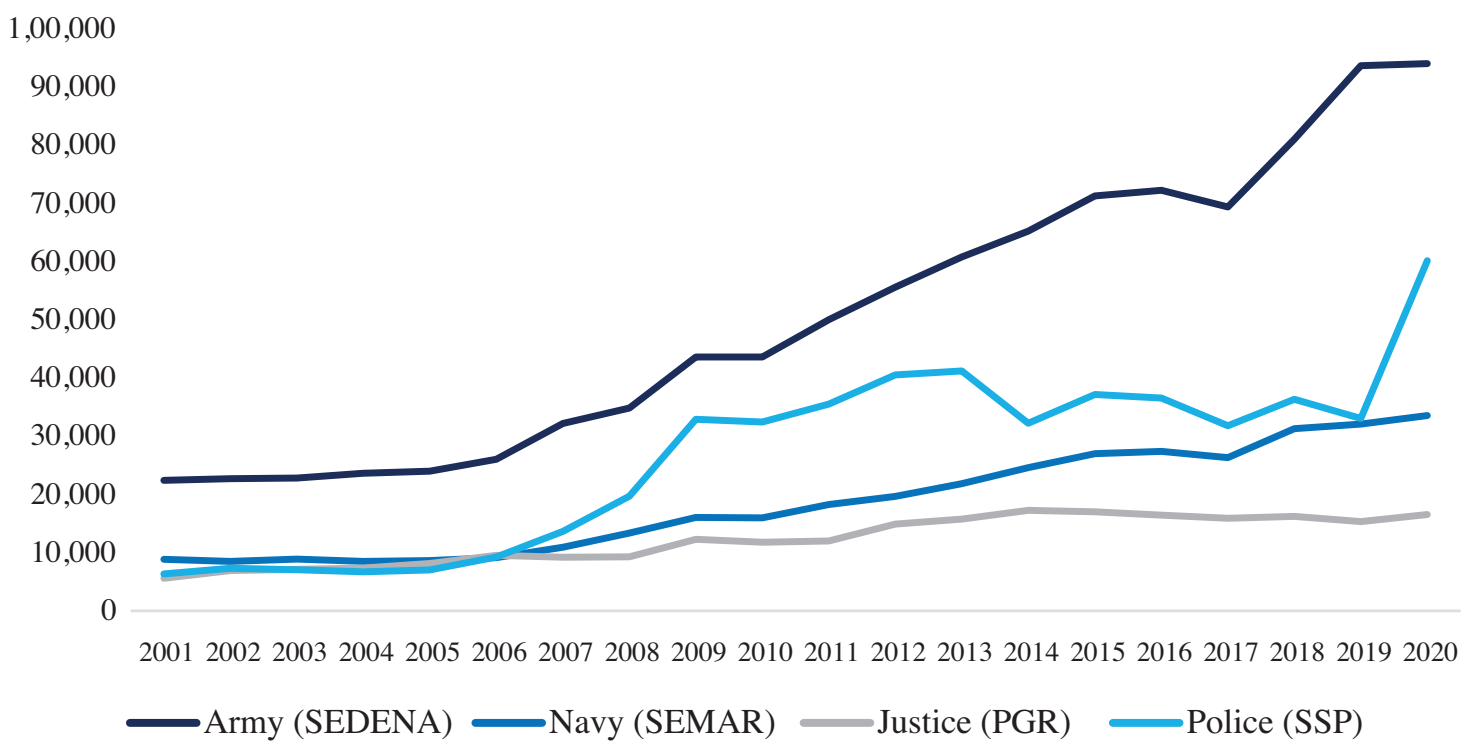

Figure 1. Evolution of public spending on security (2001-2020) (millions of pesos) Source: Federation Expenses Budget (Cámara de Diputados, 2001-2020)

As a field in dispute, the new government's security policy revealed the bureaucratic and organizational distinction capacity of the Armed Forces, at least in terms of the assigned budget and the institutional autonomy for its exercise. Public spending on security showed a vertiginous increase, destined for two organisms in particular: the Secretariat of Public Security (SSP), whose budget quadrupled between 2006 and 2012from about 9,300 million pesos to more than 40,000 — and the Army (SEDENA), which doubled its spending - from around 26,000 million to over 55,000 (Figure 1).

This budget increase contrasts with the previous administration, led by Vicente Fox (2000-2006). On the one hand, it followed a period of financial stability in which military spending had been maintained, with a moderate average increase of $16 \%$ for the Army in this period and just 3\% for the Navy. On the other hand, it is also distinguished from the previous period in that the Fox government had strengthened the budgets of civil security institutions, with an increase of $71 \%$ for justice (PGR) and $46 \%$ for police (SSP) (Table 2). This illustrates the militaristic turn of the Calderón government. If we expand the comparison between the four State security secretariats (SEDENA, SEMAR, SSP and PGR) and the two main secretariats beneficent in nature-education (SEP) and health - we observe that - although the annual growth rates of their respective budgets are unequal — during these two governments, the most benefited secretariat was the police

police, specifically because the police institutions themselves became criminogenic actors. However, the problem of corruption is shared by the Armed Forces, as other cases have shown, such as those of Generals Gutierrez Rebollo and Acosta Chaparro, as well as the desertion of members of the special forces and their incorporation into criminal groups. In this sense, one consequence of militarization has been the increased exposure of the military to corruption and, therefore, the consolidation of its nexus with criminal interests. 
Table 2. Annual budget by State secretariat (2001-2020)

\begin{tabular}{|c|c|c|c|c|c|c|}
\hline Year & $\begin{array}{c}\text { Army } \\
\text { SEDENA }\end{array}$ & $\begin{array}{c}\text { Navy } \\
\text { SEMAR }\end{array}$ & $\begin{array}{c}\text { Justice } \\
\text { PGR / FGR }\end{array}$ & $\begin{array}{l}\text { Police } \\
\text { SSP }\end{array}$ & $\begin{array}{c}\text { Education } \\
\text { SEP } \\
\end{array}$ & Health \\
\hline 2001 & 22,425 & 8,873 & 5,594 & 6,350 & 97,569 & 19,278 \\
\hline 2002 & 22,705 & 8,518 & 6,933 & 7,320 & 110,377 & 21,996 \\
\hline 2003 & 22,831 & 8,889 & 7,154 & 7,067 & 106,355 & 20,867 \\
\hline 2004 & 23,629 & 8,506 & 7,371 & 6,720 & 109,588 & 21,422 \\
\hline 2005 & 24,002 & 8,636 & 8,144 & 7,037 & 127,668 & 34,024 \\
\hline 2006 & 26,032 & 9,164 & 9,551 & 9,274 & 137,590 & 42,356 \\
\hline $\begin{array}{l}\text { Six-year } \\
\text { Evolution }\end{array}$ & $16 \%$ & $3 \%$ & $71 \%$ & $46 \%$ & $41 \%$ & $120 \%$ \\
\hline 2007 & 32,201 & 10,951 & 9,217 & 13,665 & 151,963 & 55,583 \\
\hline 2008 & 34,861 & 13,383 & 9,308 & 19,712 & 173,498 & 69,426 \\
\hline 2009 & 43,623 & 16,059 & 12,310 & 32,917 & 200,931 & 85,036 \\
\hline 2010 & 43,632 & 15,992 & 11,781 & 32,438 & 211,186 & 89,893 \\
\hline 2011 & 50,039 & 18,270 & 11,998 & 35,519 & 230,685 & 105,314 \\
\hline 2012 & 55,611 & 19,680 & 14,905 & 40,537 & 251,765 & 113,480 \\
\hline $\begin{array}{l}\text { Six-year } \\
\text { Evolution }\end{array}$ & $73 \%$ & $80 \%$ & $62 \%$ & $197 \%$ & $66 \%$ & $104 \%$ \\
\hline 2013 & 60,811 & 21,865 & 15,761 & 41,217 & 260,277 & 121,857 \\
\hline 2014 & 65,237 & 24,603 & 17,288 & 32,250 & 292,549 & 130,265 \\
\hline 2015 & 71,274 & 27,026 & 17,029 & 37,174 & 305,057 & 134,848 \\
\hline 2016 & 72,251 & 27,401 & 16,469 & 36,570 & 302,987 & 132,217 \\
\hline 2017 & 69,408 & 26,337 & 15,897 & 31,798 & 267,655 & 121,818 \\
\hline 2018 & 81,022 & 31,307 & 16,244 & 36,371 & 280,969 & 122,557 \\
\hline $\begin{array}{l}\text { Six-year } \\
\text { Evolution }\end{array}$ & $33 \%$ & $43 \%$ & $3 \%$ & $-12 \%$ & $8 \%$ & $0.6 \%$ \\
\hline 2019 & 93,670 & 32,083 & 15,351 & 33,067 & 308,000 & 124,267 \\
\hline 2020 & 94,029 & 33,558 & 16,572 & 60,151 & 326,282 & 128,826 \\
\hline
\end{tabular}

Source: Federation Expenses Budget (Cámara de Diputados, 2001-2020)

(SSP), with an average annual growth of over 20\% throughout the period (2001-2012) according to Federation Expenses Budget (Cámara de Diputados, 2001-2020).

With the drastic increase in spending on public security, the interests of militarization were sharpened. The occupation of key positions within the police and judicial organisms, at the different levels of government, became increasingly strategic. The best example of this situation is found in the Attorney General's Office (PGR) (Artz, 2003), at the head of which General Rafael Macedo de la Concha was appointed in 2000. Three years later, "there were around 200 military commissioners in the PGR. Among them, 20 were coordinators or operational directors" (Morales; Pérez Ricart, 2014b, p. 22). In 2007, several of the internal directorates became ruled by the Air Force, while the Army took control of the Assistant Attorney General's Office for Special Investigations on Organized 
Crime (SIEDO). The military "assault" on the Office is of such magnitude "that it will give the well-founded impression of a subordination of the PGR to SEDENA, and not a mere adjunct of the second to the first, as it had been legally established since 1947" (Astorga, 2007, p. 38).

Numerous active and retired military personnel were appointed to high-level positions throughout those years. As Alvarado and Zaverucha (2010, p. 247) show, "this presence has been increasing particularly in command and operational positions, at the head of the police forces in several important municipalities, as well as in some directorates or regional security secretariats." As a result of this process of militarization, according to calculations by Moloeznik and Suárez (2012, p. 134), in 2012, 14 of the 32 Mexican states had a public security secretary with a military background. Finally, as another example, a unique command system was created at the national level in 2010 which ultimately subordinated police corporations to military command.

\section{VIOLENCE AND VIOLATION OF HUMAN RIGHTS}

The capture of civil security institutions by military interests lead to the imposition of war logics in their operation. On the one hand, police corps took an increasingly subordinate position to the Army, through devices such as the BOM, which presented an average of 62 annual operations between 2006 and 2012 (Morales and Pérez Ricart, 2014b, p. 26), through the installation of 180 bases in 26 states up to 2017 (SEDENA, 2017). On the other, the combined interventions between the Armed Forces and police corporations were multiplied in various states of the country to which troop convoys arrived. These were the so-called "joint operations" (operativos conjuntos), in which the Army, the Navy, the Federal Police and the PGR participated under military command. Their implementation ran from 2006 to 2014, that is, through three different federal administrations, for a total of 15 operations deployed throughout the national territory (Atuesta, 2018).

As a series of investigations has shown (Escalante, 2011; Merino, 2011; Morales, 2012; Atuesta, 2018), these operations contributed decisively to the increase in violence in the states where they were carried out. Indeed, although crime-related violence showed an increase in different regions prior to intervention - as Vilalta (2014) suggests - the deployment of the Armed Forces significantly modified the dynamics of violence. Thus, a systematic correlation is observed, at a statistical level, between the implementation of joint operations and the positive evolution of the homicide rate, in the times and spaces of these operations. The evidence provided by these investigations shows the link between militarization and violence, and it stands in contrast to a dominant vision that usually imputes the cause of the increase in violence to the sole criminal action.

In this sense, military intervention in public security tasks poses a significant social and institutional challenge for human rights, considering that the Armed Forces are socialized for the maximum use of force. Their preparation for war admits a clear separation between the military and civilians, where the latter are in an evident disadvantage that makes it difficult "to achieve the balance between force protection and target protection" (Pion-Berlin, 2017, p. 3). Under this premise, military intervention in both the anti-drug 


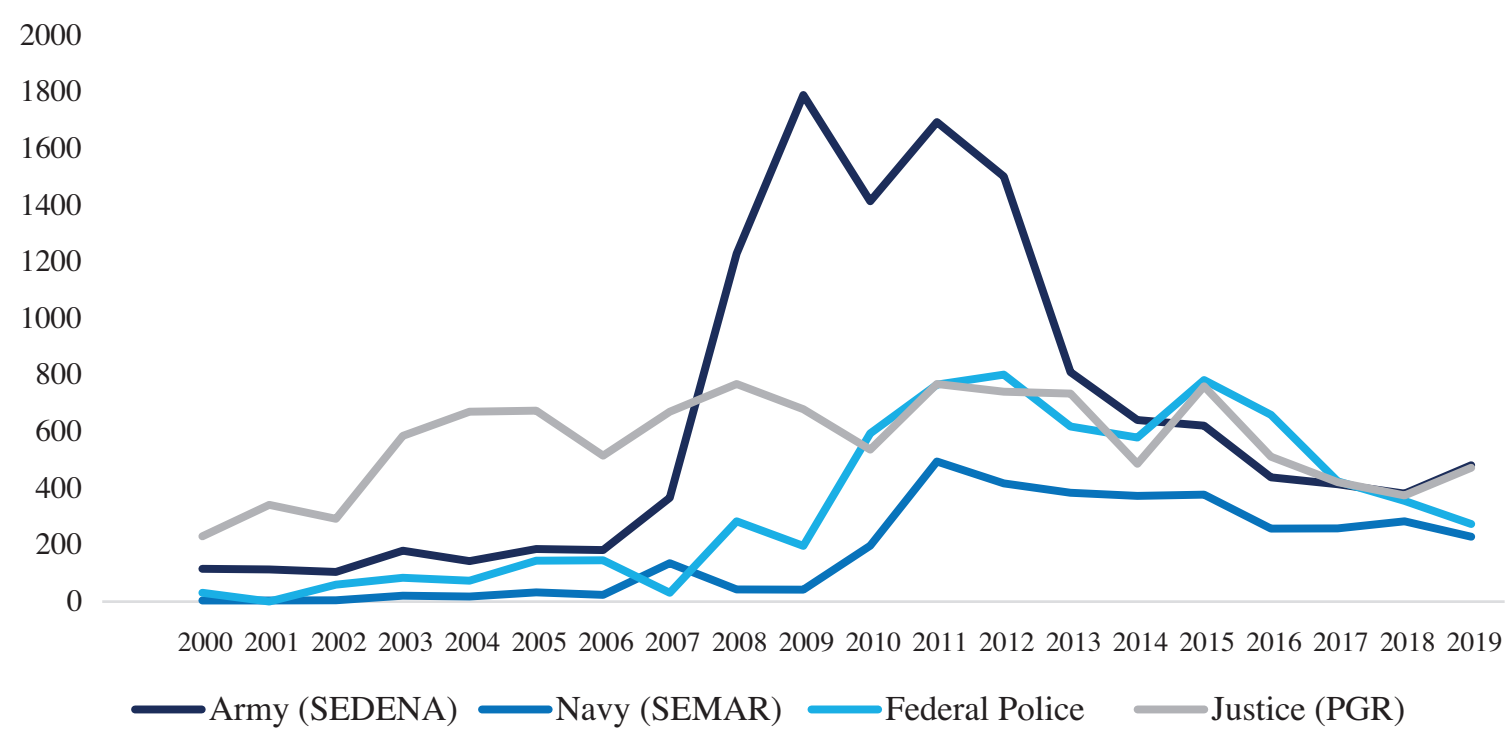

Figure 2. Complaints to the National Human Rights Commission for human rights violations (2000-2019)

Source: National Human Rights Commission (CNDH, 2000-2019)

fight and police tasks can only be associated with an increase in the levels of arbitrariness and human rights violations. In Mexico, the two critical junctures that represent the Dirty War in the seventies and the Zapatista uprising in the nineties, were warnings of this danger, with a record of numerous and serious human rights violations - as in the case of massacres, extrajudicial executions and enforced disappearances (Femospp, 2006; Comverdad, 2014). Furthermore, several human rights reports had pointed out the negative effects of military interventionism on internal security (CIDH, 1998; Jahangir, 1999; CNDH, 2001).

A first indicator of this problem is found in the number of complaints to the National Human Rights Commission (CNDH). Indeed, this indicator has experienced sustained and continuous growth from 2006 onwards, throughout the Calderón government, as a sign of the improper performance of the military, police and judicial institutions, in a direct relationship with joint operations. From 2006 to 2011, the annual number of complaints multiplied, going from 24 to 418 against the Navy, from 146 to 775 against the Federal Police, from 515 to 769 against the Attorney General's Office (PGR), and from 182 to 1,695 against the Army, that is to say, from 867 to 3,734 complaints in total, for a growth rate of $430 \%$ in the period (Figure 2).

The institution indicated as responsible for violations of human rights in greater proportion is, by far, the Army, with an annual number of complaints that has almost multiplied by 10 , drawing the peak observed in the graph. In this sense, while the PGR showed conflictive behavior prior to this period - its levels have remained relatively stable before and after the Calderón government - the judicial institution differs from its military and police peers, who experienced a significant increase in complaints in the scenario of militarization built by the "war on drugs." 
Although complaints decreased during the Peña Nieto government (2012-2018), the levels at which they tended to stabilize from 2014 continued to be higher than the numbers registered before the joint operations. This is the case for complaints made to the Navy, whose level remains stable and high. In the case of the Federal Police, the decrease in complaints against the corporation is late, occurring only since 2017 . However, the quantitative decrease in the number of complaints does not necessarily express a qualitative reduction in human rights violations. This difference is due to several reasons, but mainly to the gap between the official statistics and the diverse and complex reality of concrete situations. As Anaya (2015, p. 59) warns, "it is very difficult for certain acts (such as extrajudicial execution, torture or enforced disappearance) to have administrative records that reliably demonstrate all the cases of violations that have occurred."

Furthermore, the aggregation resulting from the sum of events cannot account for their nature, nor for their evolution in qualitative terms, that is, the type of violations committed and how they occur specifically. It fails even more to explain institutional changes linked to militarization, to determine how the relationship of corporations -Armed Forces and police- with the use of violence has evolved, or what perception their agents have built about human rights for the performance of their functions. To fill this void, some recent research works have disaggregated the data and focused their attention on a single type of human rights violation, such as torture (Magaloni, Magaloni and Razu, 2018; Silva and Padilla, 2019, 2020). This has also been the case of lethality in the use of public force, which we will review below, due to the suggestive results that have been produced by studies on this subject.

Regarding to topic, it is necessary to point out that in the last decade, there has been an important debate about the need to define mechanisms and protocols that allow regulating the use of force, considering that the deployment of the Armed Forces in public security tasks began in a context of total omission about the implementation of controls aimed at preventing the occurrence of cases of police and military abuse. As a late response, not only to the increase in the number of cases of serious human rights violations, but also to the Constitutional reform of 2011 - that established a new juridical paradigm and the mandate for State agents to minimize any risk that endangers to human rights in the performance of their functions-,${ }^{5}$ in 2012, a Directive that regulates the legitimate use of force by Armed Forces personnel was published, and later, in 2014, a Manual of the use of force of common application to the three federal forces. However, both this directive and said manual have shown to have minimal effects on police and military operations.

\section{LeTHALITY IN THE USE OF PUBLIC FORCE}

The general growth in the number of complaints for human rights violations is due, in large part, to the increasing violence that goes along with the militarization of public

\footnotetext{
${ }^{5}$ One of the most relevant issues of the constitutional reform was the binding nature of the jurisprudence of the Inter-American Court of Human Rights (IACHR) and other international treaties, which forced the Mexican State to adopt and adapt the national regulatory framework to comply with the Basic Principles on the Use of Force and Firearms by Officials in Charge of Enforcing the Law of the United Nations, as well as the jurisprudence on the use of force derived from the judgments of the Court.
} 


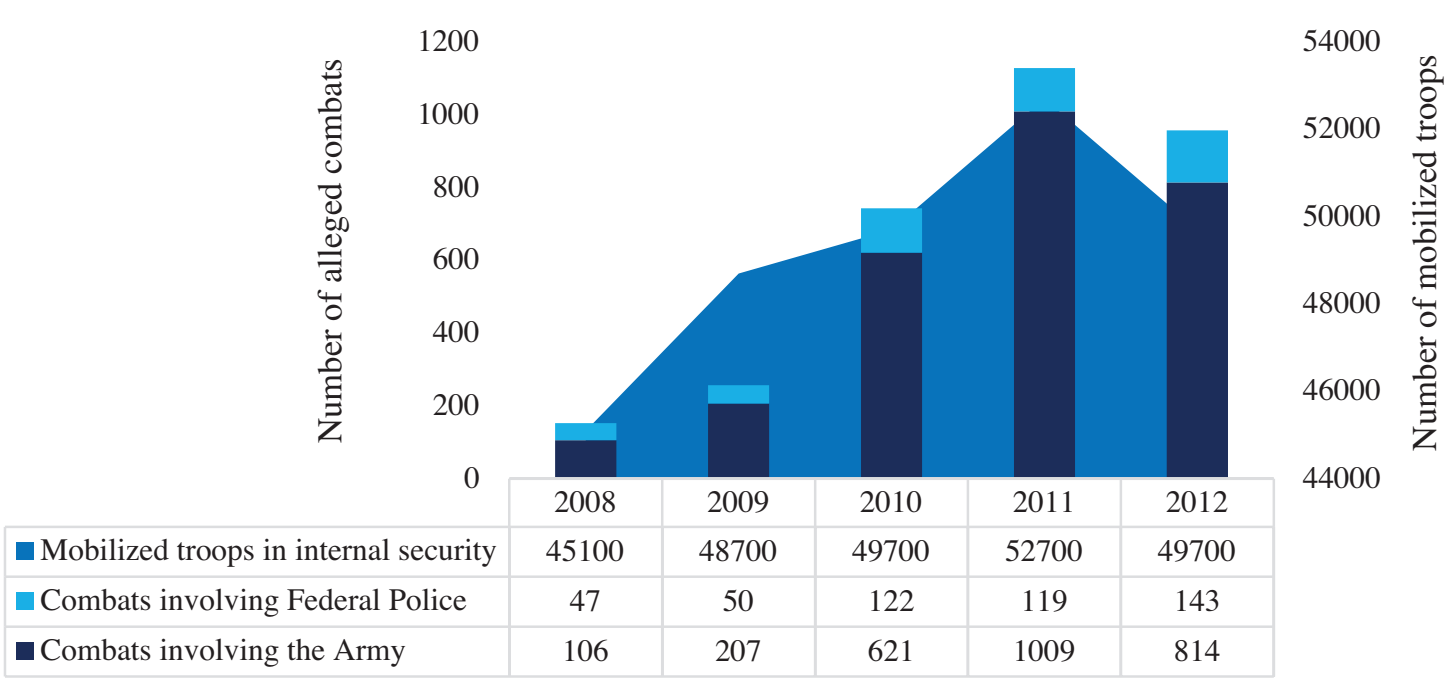

Figure 3. Mobilized military troops in internal security and alleged combats with Army and Federal Police personnel (2008-2012)

Sources (Silva, Pérez Correa and Gutiérrez, 2017, p. 339-340; Benitez and Aguayo, 2017, p. 271)

security, particularly visible in the alleged combats in which State forces are involved. Indeed, the number of these confrontations with supposed criminal groups has grown dramatically since 2010 , on par with the number of troops deployed. Thus, while the number of mobilized Army troops in internal security tasks did not stop increasing between 2008 and 2011 - from 45100 to 52700 - the number of alleged combats involving the military grew exponentially, from 106 to more than 1000 in the same period (Figure 3).

In relation to these alleged combats with criminal groups, a recent investigation (Madrazo, Calzada and Romero, 2018), supported by a solid database, shows that, of all the combats registered between 2007 and 2011 at the national level, only 7\% have been caused by civilians - suspected criminals - while the vast majority ( $84 \%$ ) have been triggered by State forces, be they military or police. Furthermore, of all these combats, only $5 \%$ have occurred as the result of a court order or in the framework of a judicial investigation, while $75 \%$ of the armed clashes are due to the mere physical presence of State forces, during patrols (38\%) or other operations without explicit objectives (8\%), outside their facilities $(25 \%)$, in an apparently fortuitous and unforeseen manner. On the other hand, activities with prior planning, such as the installation of checkpoints (4\%) or crop eradication $(0.5 \%)$, present residual percentages as activities that trigger combats. In sum, these numbers illustrate that the main risk factor is not criminal — as might be expected-but institutional, insofar as the cause of most combats is on the side of security forces. In other words, the increasing fighting obeys the warlike logic of militarization, which makes them proactively seek an enemy to fight.

Consequently, the lethality of military and police corporations increases at the rate of combats, expressing an excessive, illegal and systematic use of violence. This deadly force is shown by another investigation, based on press monitoring, (Silva, Pérez Correa and Gutiérrez, 2012, 2017). As with the previous research, the results are suggestive. 
Table 3. Lethality of State forces in alleged combats (2008-2014)

\begin{tabular}{|c|c|c|c|c|c|c|c|c|c|}
\hline \multicolumn{2}{|c|}{ Year } & $\mathbf{2 0 0 8}$ & $\mathbf{2 0 0 9}$ & $\mathbf{2 0 1 0}$ & $\mathbf{2 0 1 1}$ & $\mathbf{2 0 1 2}$ & $\mathbf{2 0 1 3}$ & $\mathbf{2 0 1 4}$ & Total \\
\hline $\begin{array}{c}\text { Army } \\
\text { SEDENA }\end{array}$ & Dead civilians & 44 & 95 & 327 & 526 & 370 & 225 & 168 & 1755 \\
\hline & Wounded civilians & 13 & 24 & 40 & 27 & 23 & 19 & 23 & 169 \\
\hline & Lethality rate & 3.4 & 4 & 8.2 & $\mathbf{1 9 . 5}$ & 16 & 11.8 & 7.3 & 10 \\
\hline $\begin{array}{c}\text { Federal } \\
\text { Police }\end{array}$ & Dead civilians & 44 & 74 & 35 & 92 & 162 & 65 & 51 & 523 \\
\hline & Wounded civilians & 19 & 17 & 9 & 3 & 13 & 16 & 2 & 79 \\
\hline & Lethality rate & 2.3 & 4.4 & 4 & $\mathbf{3 0 . 7}$ & 12.5 & 4 & $\mathbf{2 5 . 5}$ & 6.6 \\
\hline $\begin{array}{c}\text { Navy } \\
\text { SEMAR }\end{array}$ & Dead civilians & - & 24 & 50 & 103 & 36 & 33 & 74 & 320 \\
\hline & Wounded civilians & - & 6 & 2 & 7 & 1 & 2 & 1 & 19 \\
\hline & Lethality rate & - & 4 & $\mathbf{2 5}$ & 15 & $\mathbf{3 6}$ & 17 & $\mathbf{7 4}$ & 17 \\
\hline
\end{tabular}

Source (Silva, Pérez Correa and Gutiérrez, 2017, p. 344)

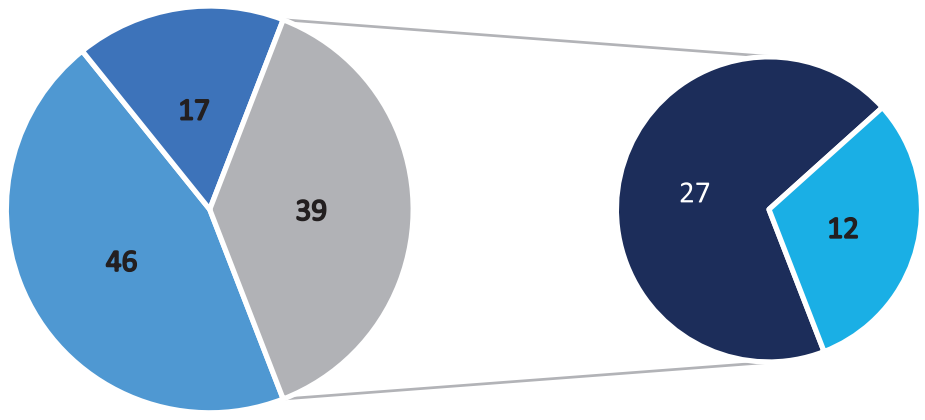

- No civilians killed or wounded

- With civilians dead and wounded

- Only with dead civilians killed by military

- Only with dead civilians killed by police

Figure 4. Perfect lethality of State forces in alleged combats (2007-2011)

Source (Madrazo, Calzada and Romero, 2018, p. 395)

Indeed, as a result of these alleged combats, there are more civilians killed than wounded, and more wounded than detained, unlike a normal situation in which the relationship is exactly the opposite. "Even the medical literature, when analyzing the use of conventional weapons in armed conflicts, inverts the index to report wounded over dead, as the former are more common than the latter in contexts of war [...] The index is instead reversed when it deals with war crimes or shootings against civilians" (Silva, Pérez Correa and Gutiérrez, 2017, pp. 343-344). Thus, in a militarized Mexico, for each military or policeman killed in combat, the ratio of wounded and killed civilians is increasingly large. Likewise, while the number of injuries is greater than the number of deaths among State forces- this result being what is normally expected - there is an opposite trend among civilians, with a number of deaths that is always much greater than the number of wounded. It is this difference that we understand as the lethality index.

From 2010 onwards, with the deepening of the war scheme, the lethality of State forces increased dramatically, in such a way that, in the following two years, the Federal 
Police, the Army, and the Navy systematically showed rates higher than 10 points - that is, greater than 10 deaths for each wounded - with peaks at 19.5 for the Army and 30.7 for the Federal Police in 2011, and another at 36 for the Navy in 2012 (Table 3). In comparative terms, it is the Navy that exhibits the highest lethality rates, with an average of 17 points in the 2008-2014 period, above the Army (10) and the Federal Police (6.6). Likewise, the combats in which the military or marines intervene are deadlier than those where only the police participate. In this sense, "the inclusion of the Army in security tasks, in violent environments, seems to bring with it an inevitable use of force under a logic of war, and it is possible that another outcome is unlikely based on the characteristics of military formation" (Silva, Pérez Correa and Gutiérrez, 2012, p. 63).

In addition, if we observe the perfect lethality of State forces - that is, the events in which the dead are exclusively civilians and where there is not even a single wounded, be it a civilian or an official - the proportion of these events is considerable. Perfect lethality cases account for 39\% of all the alleged combats between 2007 and 2011, of which 27\% involve the military and $12 \%$ the police (Figure 4). Additionally, these events are the ones that contribute the most registered civilian deaths, representing $90 \%$ of the combats with military intervention and $77 \%$ with police participation in the same period (Madrazo, Calzada and Romero, 2018, p. 395).

In other words, in more than a third of the alleged combats with criminal groups, as well as in the vast majority of cases with civilian deaths, this perfect lethality suggests that, rather than fighting between officials and criminals, in reality, it is probably about extrajudicial or arbitrary executions. ${ }^{6}$ It is what both investigations on lethality in the use of public force imply. In Mexico, we would find ourselves not only facing a deterioration of human rights due to an aggravation of its violations, but also before State crimes, whose logic obeys the warlike scheme that sustains the processes of militarization. When public security is intervened by military interests, crime prevention becomes a prosecution of criminals. Fighting crime leads to a war against the "enemy." As a result of this conversion, warlike logic condemns the alleged criminals to annihilation. This is what these lethality rates suggest.

The United Nations Special Rapporteur on extrajudicial, summary or arbitrary executions, Christof Heyns, visited Mexico in 2014. In his final report, he referred to 31 cases of summary executions between 2007 and 2012 at the hands of the Armed Forces and the police (Heyns, 2014, p. 5). A few months after this visit, the events of Tlatlaya and Iguala occurred - in the latter case, with the disappearance of the 43 students from Ayotzinapa. In 2015, the events of Apatzingán, Tanhuato and Ostula in Michoacán followed, and in 2016, those of Nochixtlán in Oaxaca. All these cases stand out for the

\footnotetext{
${ }^{6}$ The Minnesota Protocol on the Investigation of Potentially Unlawful Death (UN, 2016) considers that extrajudicial, summary or arbitrary executions occur when "the death may have been caused by acts or omissions of the State, its organs or agents, or may otherwise be attributable to the State." In these cases, all the executions possibly carried out by State agents are contemplated, but also by private security agents in the exercise of State functions, by paramilitary groups or militias under the direction of the State, and also when death occurs while the victim was detained or in the custody of State agents.
} 


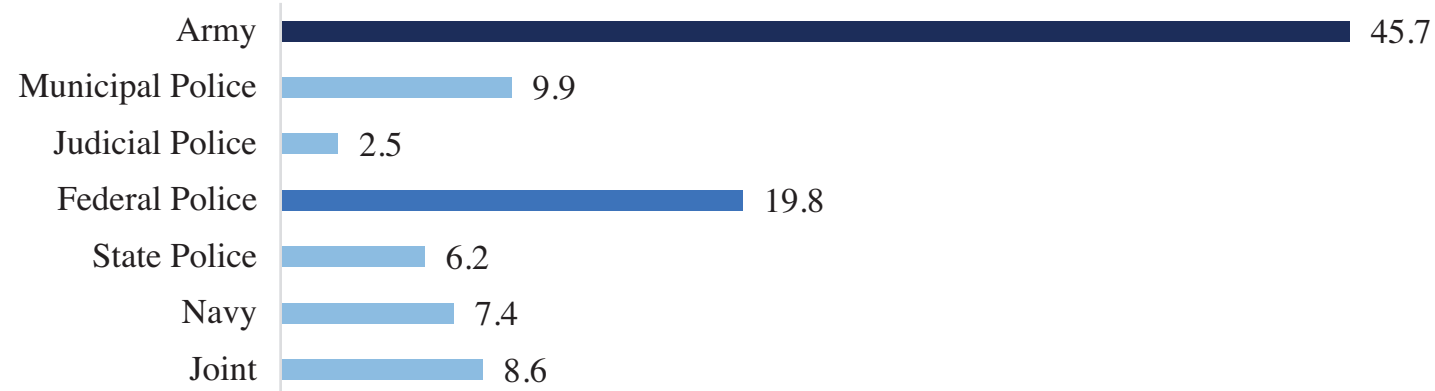

Figure 5. Corporations responsible for extrajudicial executions (2006-2020)

Sources: National Human Rights Commission (CNDH, 2006-2020)

excessive use of force and its lethality. Based on this report, and on the National Human Rights Commission's recommendations on these different cases, between 2006 and 2020 we have been able to count at least 81 cases of extrajudicial executions in the country. However, due to the absence of statistics, this number only represents an approximation that is probably lower than the real figures. It should also be noted that $60 \%$ of the identified cases are concentrated between 2008 and 2012, during Calderón's government, and that the Army has been the responsible institution in almost half of all cases (46\%), followed by the Federal Police (20\%) and the municipal police (10\%) (Figure 5).

Moreover, in the same way as in the case of complaints filed for human rights violations, lethality rates cannot account for specific problems. If they indicate general guidelines on the behavior of security institutions, they cannot explain how the commission of extrajudicial executions is made possible. In this sense, it is necessary to accompany the quantitative investigations with qualitative works, based on case studies, that allow us to understand, beyond the general logic of militarization, the conditions and circumstances that make these cases possible. It is for this reason that we will deal with the issue through a case study based on an event that, in recent years, has become one of the most emblematic in the matter: the Tlatlaya case.

\section{Extrajudicial EXecutions: The Tlatlaya CASE}

On June 30, 2014, various media reported — as had been recurring since 2007-a clash between a military patrol (assigned to the 102nd Infantry Battalion) and a group of alleged criminals in San Pedro Limón, in the municipality of Tlatlaya, State of Mexico. On the night of this day, the Army communicated - via Twitter - the following message: "Today, military personnel conducting reconnaissance in Tlatlaya, State of Mexico, located a warehouse guarded by four civilians. These persons opened fire on the troops, who repelled the attack resulting in 22 dead attackers. At the site, 38 weapons and ammunition were seized, and three women were released, who were placed at the disposal of the corresponding authority. In these events, a military element was wounded."

However, a few days later, on July 8, an Associated Press reporter, Mark Stevenson (2014), released a note questioning this official version. In his article, the foreign journalist 
explains how his on-site visit, three days after the events, allowed him to observe "little evidence of sustained fighting." Instead, he found several clues whose concentrationparticularly blood stains and bullet holes in a wall-seemed to coincide rather with possible executions, in which the victims would have been lined up against the wall and shot at chest height. Due to this article, as well as a growing international demand for the clarification of the facts - from InSight Crime and Human Rights Watch particularlythe local Attorney General's Office (citado en Senado de la República, 2015) issued a statement saying the following: "There were no shots fired at close range; cross fire was proportional; according to the trajectory of projectiles and the position in which the bodies were found, [there is] no indication of a possible execution."

On September 17, a new press article was published (Ferri, 2014), containing the key testimony of one of the three "liberated" women, who was allegedly kidnapped. Identifying herself as the mother of one of the victims, a 15-year-old girl, she stated that it was the military who started shooting, that only one of the victims died in the crossfire, and that all the other people soon surrendered. After submitting, the victims were interrogated, tortured, and executed by the soldiers: "Then [the military] asked for their names and wounded them; at first they did not kill them. I said 'no, don't do it,' but they said that 'those dogs don't deserve to live' [...] Then they lined them up and killed them" (Ferri, 2014). The interviewee also related how her daughter was wounded in the leg by one of the militaries and, when she tried to help her, the soldiers held her and killed her daughter, who was immobilized on the floor, shooting her in the chest. Later, the military "put on gloves and turned her upside down" (Ferri, 2014). In this way, the testimony not only reinforced the hypothesis formulated by Stevenson, but also accounted for a possible modification of the scene to cover up executions and to fake combat.

On September 19, two days after the publication of this testimony, the Army issued another statement (SEDENA, 2014), now offering "its unrestricted collaboration with the competent authority to clarify the facts and determine the legal truth about this event." As another consequence of this testimony, the National Human Rights Commission (CNDH) opened an investigation into the case, even if it was late. On the 24th, the president of the Commission, Raúl Plascencia Villanueva, was still defending the official version of a simple confrontation (Rivera, 2014). However, on the 26th-a few hours before the events of Iguala - anticipating the possible unfavorable result of said investigation, the Secretary of the Interior, Miguel Ángel Osorio Chong, affirmed that, if the suspicions were confirmed, it would only be "an isolated action," not representative of military action.

In its 51 recommendation of October 21, the CNDH (2014) presented the main results of its investigation. The victims included three minors, as well as eleven young people aged between 18 and 23, most of them belonging to rural communities. The events occurred at least one hour before what the Army indicated. Of the 38 weapons seized, only 11 were fired and 8 directly related to a victim, that is, while a minority shot against the military, the majority tried to take refuge or flee the fire. Likewise, the 22 dead victims presented wounds resulting from a single shot, with a perpetrator systematically positioned in front of his victim. In this way, the $\mathrm{CNDH}$ assured that only four of the victims died in 
the confrontation, and three more in the crossfire, while the remaining 15 were arbitrarily executed.

Thus, the CNDH rejected the version of the local Attorney General's Office on an alleged combat for not having "sufficient elements to reach this conclusion, which is also erroneous considering that, in various conclusions, it is exposed that some bodies have instinctive defensive positions" (CNDH, 2014, p. 82). On the other hand, the CNDH managed to prove the alteration of the crime scene by the military, with the help of other troops who came after the massacre, "with the intention, most likely, to simulate that deaths had occurred in a context of combat [...] the bodies were moved from their original location and repositioned. In addition, phones were stolen from the scene" (CNDH, 2014, p. 27). In sum-despite various limitations - the Commission's investigation confirmed the information contained in the two previous press articles, recognizing both the reality of extrajudicial executions and official attempts to cover them up.

Even considering it as a particular case, the facts that occurred in Tlatlaya do not represent an isolated event but are part of a series of aforementioned cases in which the military and police corporations committed serious violations of human rights. In this sense, beyond its uniqueness, the Tlatlaya case is even more relevant for three fundamental reasons: 1) because the participation of the Armed Forces in extrajudicial executions was officially accredited; 2) because it is the first case of human rights violation committed by the military that could be investigated by civil justice, due to a reform to the Code of Military Justice - also in 2014 — and, 3) because it is the only case of summary executions that has been sentenced to date. In addition, the Tlatlaya case allows for testing the civil control mechanisms over the Armed Forces, showing the obstacles that the extension of military jurisdiction represents, both for the clarification of the facts, and for justice for the victims.

In relation to this last point, it should be remembered that the Mexican Armed Forces have historically benefited from a set of prerogatives that have assured them important institutional autonomy. The lack of civil controls on their activities, in turn, has favored the construction of an action framework characterized by opacity, secrecy, and impunity. According to Stepan and Wolfson (1988, p. 93), these prerogatives refer to those spaces in which the "military have the acquired right or privilege, formal or informal, to exercise effective control over their internal management procedures, to perform a role in extra-military areas of the State apparatus, or even to structure relations between the State and political or civil society." Both authors identify, as an indicator of "high" military prerogatives, the prevalence of military jurisdiction over civil justice, that is, the impossibility or low probability that military elements will be submitted to civil courts in case of human rights violations.

In Mexico, constitutional and historical antecedents of military jurisdiction refer to different moments in which it was restricted to crimes and offenses that had a strict connection with military discipline - following the constitutional formula - granting civil justice in those cases in which the parties involved were military and civilians. However, due to the absence of precise legal pronouncements regarding the restriction of military 
jurisdiction over cases in which civilians constitute a passive object, as well as the high degree of autonomy and secrecy that characterize the Armed Forces, civil authorities have declined their jurisdiction in favor of the military (Cossío, 2010). In this way, both the investigation of human rights violations and the sanction of responsible agents have been made impossible, as occurred in the cases of Radilla Pacheco (1974), Cabrera García and Montiel Flores (1999), Rosendo Cantú (2002), Rubio Villegas (2009), Mercado and Arredondo Verdugo (2010), among the main examples.

In the case of the Radilla Pacheco v. Mexico ruling (2009), the Inter-American Court of Human Rights ordered the Mexican State to enhance the necessary legislative adjustments to article 57 of the Code of Military Justice in order to homogenize the regulation of military jurisdiction with international standards. As a result, in 2014 the article was amended, specifying that crimes in which the military and civilians concur will be the competence of civil authority. This is how the Tlatlaya case could be one of the first cases of human rights violations to be investigated after this reform. However, six years after its implementation, and in light of the unfinished aftermath of the case, it is possible to identify important gaps in the 2014 reform that hinder the judicial investigation,

Table 4. Chronology of judicial actions in the Tlatlaya case

\begin{tabular}{|c|c|}
\hline $02 / 09 / 14$ & $\begin{array}{l}\text { The Army reported that the eight elements involved-seven soldiers and a } \\
\text { lieutenant-were presented to the Sixth Military Court and interned in the prison } \\
\text { attached to the First Military Region. Their release on bail was denied after } \\
\text { knowing the start of an investigation by the Attorney General's Office. }\end{array}$ \\
\hline $07 / 11 / 14$ & $\begin{array}{l}\text { The Federal Judicial Council announced the consignment of the military } \\
\text { before the Fourth District Court of Federal Criminal Proceedings, in the State } \\
\text { of Mexico, for the following charges: improper exercise of public service, abuse } \\
\text { of authority, aggravated qualified homicide, illegal alteration of crime scene } \\
\text { and cover-up. }\end{array}$ \\
\hline $31 / 03 / 16$ & $\begin{array}{l}\text { The Military Attorney General's Office acquitted the seven soldiers of offense for } \\
\text { breach of duty. Four soldiers were exonerated in the case, while the lieutenant- } \\
\text { the only officer involved-was sentenced to one year in prison for disobedience, } \\
\text { but not for homicide. }\end{array}$ \\
\hline $13 / 05 / 16$ & $\begin{array}{l}\text { A judicial resolution (Toca Penal 247/2015) dismissed the evidence provided by } \\
\text { the Federal Public Ministry to demonstrate culpability, indicating that the evidence } \\
\text { was insufficient to prosecute the military considered responsible. }\end{array}$ \\
\hline $25 / 05 / 18$ & $\begin{array}{l}\text { The Fourteenth District Court of Amparo in Criminal Matters, in Mexico City, } \\
\text { ordered the Attorney General's Office to carry out an investigation on the case, } \\
\text { emphasizing the chain of command, as well as a military order that instructed the } \\
\text { troops "to operate at night in a massive way in order to kill criminals in hours of } \\
\text { darkness." }\end{array}$ \\
\hline $20 / 02 / 19$ & $\begin{array}{l}\text { The Second Chamber of the Supreme Court resolved the 998/2018 "amparo," in } \\
\text { which the principle of maximum publicity was analyzed in relation to information } \\
\text { on serious human rights violations, resolving the possibility of reproducing the } \\
\text { information contained in files in which these types of violations were investigated. }\end{array}$ \\
\hline $17 / 10 / 19$ & $\begin{array}{l}\text { The Sixth Unitary Court of the State of Mexico resolved that the military must be } \\
\text { prosecuted for an improper exercise of public service. It was noted that three of the } \\
\text { soldiers involved have open investigations for the crime of qualified homicide. }\end{array}$ \\
\hline
\end{tabular}

Source: Elaborated by the authors 
perpetuate the situation of impunity, and highlight the shortcomings of civil controls over military institutions.

Regarding the judicial process itself, it is worth noting that so far, several actions have been issued in the Tlatlaya case. Moreover, even in contravention of the 2014 reform, military jurisdiction has carried out an important role of interference in the process. This is what the Centro Prodh (2015) - a human rights NGO which has assumed the legal representation of one of the victims - has pointed out. Both the Military Public Ministry and the Military Attorney General's Office have carried out proceedings that do not strictly correspond to the investigation of crimes related to military discipline. As a result, simultaneous judicial processes were opened with possible contradictory conclusions, as shown in the following chronology (Table 4).

Within this process, among other actions, the Army's decision to transfer the agents involved to central facilities stands out, because their transportation was operated in order to avoid their release, once a criminal investigation by the civil authority was known to have begun. The presentation of the military before a civil court was made impossible. Hence, the Tlatlaya case indicates the need to deepen reforms to military jurisdiction. In particular, it shows the need to prevent the military authorities from conducting investigations before, or at the same time as, civil courts, and to limit the functions of the Military Public Ministry, related to the chain of custody and the preservation of crime scenes. Indeed, as has been recorded in several cases, there is evidence of scene alteration as a recurring practice, in relation to events in which abuses were committed by the military.

In more general terms, Tlatlaya illustrates a trend with cases of serious human rights violations in Mexico, in which the institutions involved systematically deny their responsibility, the implicated agents are protected, the seriousness of the facts is minimized, and the victims are not recognized, constituting causes of impunity with the intention of justifying the crime (Zaffaroni, 2006). In this way, the Tlatlaya case allows us to understand not only the gravity of the human rights crisis in Mexico today, but also the role played by militarization of public security and, therefore, the magnitude of problems and challenges that this militaristic scheme implies.

\section{Conclusion}

In recent years, democratic expectations have obviated the need to reform military institutions, strengthen civil controls and limit military actions in public security tasks. However, considering that militarization constitutes an extremely complex process with significant effects on police structures, the discussion cannot only be limited to strict surveillance of the Armed Forces, but also of civil institutions. As suggested by the InterAmerican Court of Human Rights - in the 2018 ruling on the case of women victims of sexual torture in the Atenco case-, a possible alternative lies in the creation of external observatories to monitor the use of force, as well as monitoring systems for police and military operations before, during and after the use of force. As the article has shown, the consequences of this omission have been clear and critical, particularly for human rights. In principle, the militarization of public security is antithetical to the possibilities of building a democratic society. On the one hand, it violates human rights - to such an extent 
that Mexico is currently in a deep crisis in the matter (Anaya and Frey, 2019)-while, on the other, it prevents their defense, hindering both accountability and civil control.

Based on the analysis of the literature and the available evidence, we consider that it can be argued consistently that a security strategy under a militaristic paradigm has not managed to have the expected effects in containing crime. On the contrary, it shows a tendency to exacerbate human rights violations as observed through numerous cases of lethality and arbitrary executions, even allowing the current context to be problematized in terms of a shift towards State crime as suggested by Zaffaroni (2006), in view of the seriousness and excessive lethality that have occurred in cases such as Tlatlaya. On the other hand, the analysis of the complaint files shows important variations within each of the federal security institutions, which leads us to think that the human rights violations that occur in the context of the militarization of public security present increasingly complex patterns of occurrence. Although the data analyzed shows a downward trend at the end of this decade, considering the underreporting in the CNDH files, it is not possible to conclude that the violation of human rights by the police and military is decreasing. Rather, it is possible to think that the increasingly broad operational powers and prerogatives of the military institutions could bring in time moments of greater discretion and human rights violations, linked to the defects present in the National Law on the Use of Force of 2019.

Current federal policies are aimed at deepening militarism. In the history of militarization that we sketch, it seems that today we are facing a third moment, marked by the adoption in 2017 of an Internal Security Law by the Peña Nieto government, and the creation in 2018 of a National Guard by López Obrador government. This last new corporation is particularly illustrative in this regard, insofar as it gives the military broad prerogatives to participate in public security, which until now lack concrete counterweight mechanisms. In effect, legal uncertainty prevails about the new institution, in terms of investigation for crime prevention, covert operations, preservation of crime scenes, detention of persons and confiscation of property, which have been granted by the National Guard Law, but in an imprecise way in regard to its control mechanisms. On the other hand, military jurisdiction remains an important point of discussion. Despite a reform to constitutional article 13, which establishes that crimes committed by National Guard members in the exercise of their functions shall be known by civil authority, disciplinary offenses will continue to be prosecuted in the military jurisdiction. This situation can probably lead, as in the Tlatlaya case, to the extension of the second over the first, with parallel judicial processes in the case of human rights violations.

Finally, the fact that militarization is maintained as the main security policy, despite the change of political regime that the 2018 general elections have supposedly represented, demonstrates the great strength that military interests have acquired within the Mexican State. This third moment seems to be distinctive, not only because it allows for the legalization of militarization - beyond the controversial nature of the Internal Security Law (Moloeznik, 2019; Gil Rendón, 2019)_-but because it contributes decisively to the institutionalization of this legalized scheme. This new moment is implemented without providing sufficient guarantees for the defense of human rights and effective civil control, and therefore, the militarization of public security in Mexico, in the immediate future, will hardly cease to pose a threat to democracy. 


\section{REFERENCES}

ALVARADO, A. y ZAVERUCHA, J. (2010) "La actuación de las Fuerzas Armadas en la seguridad pública en México y Brasil: una visión comparada", en ALVARADO A. y Serrano M. (coords.), Seguridad nacional y seguridad interior, México: El Colegio de México, pp. 227-268.

ANAYA, A. (2015) "Indicadores de derechos humanos: tipos, métodos y bases de datos existentes”, en ANSOLABEHERE, K., Valdés Ugalde, F. y Vázquez, D. (coords.), Entre el pesimismo y la esperanza: los derechos humanos en América Latina. Metodología para su estudio y medición. México: FLACSO, pp. 55-74.

ANAYA, A. y FREY, B. (eds.) (2019) Mexico's Human Rights Crisis, Philadelphia: University of Pennsylvania Press.

ARZT, S. (2003) "La militarización de la Procuraduría General de la República: riesgos para la democracia mexicana", Project on Reforming the Administration of Justice in Mexico, N. ${ }^{\circ}$ 4, La Jolla: Center for U.S. Mexican Studies.

ASTORGA, L. (2015) ¿Qué querían que hiciera? Inseguridad y delincuencia organizada en el gobierno de Felipe Calderón, Grijalbo: México.

ASTORGA, L. (2007) Seguridad, traficantes y militares, Tusquets: México.

ATUESTA, L. (2018) "Militarización de la lucha contra el narcotráfico: los operativos militares como estrategia para el combate del crimen organizado", en ATUESTA, L. y Madrazo Lajous, A. (2018), Las violencias. En busca de la política pública detrás de la guerra contra las drogas, México: CIDE.

BAGLEY, B. (1992) "Los mitos de la militarización: las Fuerzas Armadas en la guerra contra las drogas", en SMITH, P. (ed.), El combate a las drogas en América, México: Fondo de Cultura Económica, pp. 181-206.

BAILEY, J. \& DAMMERT, L. (2006) Public security and police reform in the Americas, Pittsburgh: University of Pittsburgh Press. https://doi.org/10.2307/j.ctt7zw885.

BARRÓN, M. (2003) "Militarización de la seguridad pública en México: ¿actualización o permanencia histórica?", USMEX 2003-04 Working Paper Series, San Diego: Center for U.S.-Mexican Studies, University of California.

BENÍTEZ, R. y AGUAYO, S. (eds.) (2017) Atlas de la seguridad y la defensa de México 2016, México: CASEDE.

CÁMARA DE DIPUTADOS (2001-2020) Presupuesto de egresos de la federación, México.

CAMP, R. (2010) Las fuerzas armadas en el México democrático, México: Siglo XXI.

CENTRO PRODH (2015) Tlatlaya a un año: la orden fue abatir, México: Centro de Derechos Humanos Miguel Agustín Pro-Juárez.

CIDH, Comisión Interamericana de Derechos Humanos (1998) Informe sobre la situación de los Derechos Humanos en México, OEA/Ser.L/V/II.100, Doc. 7 rev. 1, 24 de septiembre. 
CNDH (2014) Recomendación No. 51 sobre los hechos ocurridos el 30 de junio de 2014 en Cuadrilla Nueva, Comunidad San Pedro Limón, Municipio de Tlatlaya, Estado de México, México: Comisión Nacional de los Derechos Humanos.

CNDH (2006-2020) Recomendaciones y recomendaciones graves por violaciones a Derechos Humanos, México: Comisión Nacional de los Derechos Humanos.

CNDH (2001) Informe especial sobre las quejas en materia de desapariciones forzadas ocurridas en la década de los 70 y principios de los 80, México: Comisión Nacional de Derechos Humanos.

COMVERDAD (2014) Informe final de actividades, Chilpancingo: Comisión de la Verdad del estado de Guerrero.

COSSÍO, J. R. (2010) "Fuero militar: sus alcances y limitaciones." Cuestiones Constitucionales, 22, pp. 321-361. https://doi.org/10.22201/iij.24484881e.2010.22 .5914 .

DAMMERT, L. \& Bailey, J. (2015) "Reforma policial y participación militar en el combate a la delincuencia. Análisis y desafíos para América Latina." Fuerzas Armadas y Sociedad, 19(1), pp. 133-152.

DAMMERT, L. (2005) "Reforma policial en América Latina." Quórum: revista de pensamiento iberoamericano, 12, pp. 53-64.

EISSA, S. y GASTALDI, S. (2014) "Una reflexión en torno al concepto de militarización”, Documento de trabajo No. 23. Buenas Aires: Escuela de Defensa Nacional.

ESCALANTE, F. (2011) “Homicidios 2008-2009. La muerte tiene permiso.” Nexos, 1 de enero.

FEMOSPP (2006) Que no vuelva a suceder, México: Informe de la Comisión de trabajo para el esclarecimiento de la verdad histórica, Fiscalía Especial sobre Movimientos Sociales y Políticos del Pasado. FEMOSPP (2006) Que no vuelva a suceder, México: Informe de la Comisión de trabajo para el esclarecimiento de la verdad histórica, Fiscalía Especial sobre Movimientos Sociales y Políticos del Pasado.

FERRI, P. (2014) “Testigo revela ejecuciones en el Estado de México." Esquire Latinoamérica. 17 de septiembre.

FONDEVILA, G., y NAVARRETE, M. (2013) "Juego de palabras: los discursos presidenciales sobre el crimen.” Estudios Sociológicos, 31(93), pp. 721-754.

GIL RENDÓN, R. (2019) “La inconstitucionalidad de la Ley de Seguridad Interior; una afrenta al Estado de derecho en México." Cuestiones Constitucionales, 41, pp. 499-512. https://doi.org/10.22201/iij.24484881e.2019.41.13956.

HALL, A. R. y COYNE, C. J. (2013) "The Militarization of U. S. Domestic Policing." The Independent Review, 17(4), pp. 485-504.

HATHAZY, P. (2016) "La (re)militarización policial en la Argentina post-crisis: entre intereses organizacionales e instrumentalización política en los campos policiales." Dilemas, 9(1), pp. 181-213. 
HERRERA, F. \& CEDILLO, A. (Eds.) (2012) Challenging authoritarianism in Mexico. Revolutionary Struggles and the Dirty War, 1964-1982. New York: Routledge.

HEYNS, C. (2014) Informe del Relator Especial sobre las ejecuciones extrajudiciales, sumarias o arbitrarias, Misión a México, ONU.

JAHANGIR, A. (1999) Informe de la Relatora Especial relativo a las ejecuciones extrajudiciales, sumarias o arbitrarias presentado en cumplimiento de la resolución 1999/35 de la Comisión de Derechos Humanos, visita a México del 12 al 24 de julio de 1999, ONU.

JOBARD, F. (2008) "La militarisation du maintien de l'ordre, entre sociologie et histoire." Déviance et Société, 32, pp. 101-109. https://doi.org/10.3917/ds.321.0101.

KRASKA, P. (2007) "Militarization and Policing. Its Relevance to 21st Century Police." Policing, 1(4), pp. 501-513. https://doi.org/10.1093/police/pam065.

LAWSON, E. (2019) Causes and consequences of Police Militarization (Doctoral dissertation), University of South Carolina.

LAWSON, E. (2018) "Police Militarization and the Use of Lethal Force." Political Research Quartely, 72(1), pp. 177-189. https://doi.org/10.1177/1065912918784209.

LÓPEZ-MÉNENDEZ, M. (2000) "El ejército y la seguridad pública”, en BENÍTEZ et al. (2000), Siempre cerca, siempre lejos. Las Fuerzas Armadas en México, México: IEPAC, CENCOS y Global Exchange.

MADRAZO, A., CALZADA, R. y ROMERO, J. (2018) “La 'guerra contra las drogas'. Análisis de los combates de las fuerzas públicas 2006-2011." Política y gobierno, 25(2), pp. 379-402.

MAGALONI B., MAGALONI A. y RAZU Z. (2018) "La tortura como método de investigación criminal: el impacto de la guerra contra las drogas en México" en Política y Gobierno, 25(2), pp. 223-261.

MERINO, J. (2011) "Los operativos conjuntos y la tasa de homicidios: una medición." Nexos. 1 de junio.

MOLOEZNIK, M. P. (2007) "Militarización de la seguridad pública, autonomía de las Fuerzas Armadas e imperativo de la reforma militar en México." El Cotidiano, 22(146), pp. 99-107.

MOLOEZNIK, M. P. (2019) "Seguridad interior, un concepto ambiguo." Revista IUS, 13(44), 147-182. https://doi.org/10.35487/rius.v13i44.2019.458.

MOLOEZNIK, M. P. y SUÁREZ DE GARAY, M. (2012) "El proceso de militarización de la seguridad pública en México (2006-2010).” Frontera Norte, 24(48), pp. 121-144.

MORALES, M. (2012) La lucha por la seguridad en México: operativos, homicidios y crimen organizado entre 2007 y 2010, Tesis de maestría, El Colegio de México.

MORALES, S. y PÉREZ RICART, C. (2014a) "Más allá del gasto militar: en búsqueda de un concepto para entender la militarización en México", Documento de trabajo No. 1, Berlín: México vía Berlín. 
MORALES, S. y PÉREZ RICART, C. (2014b) "Militarización: una propuesta conceptual basada en el caso mexicano (1995-2012)", Documento de trabajo No. 2, Berlín: México vía Berlín.

PIÑEYRO, J. L. (2010) "Las Fuerzas Armadas mexicanas en la seguridad pública y la seguridad nacional", en ALVARADO, A. y Serrano, M. (coords.), Seguridad nacional y seguridad interior, México: El Colegio de México, pp. 156-187.

PION-BERLIN, D. (2017) "A Tale of Two Missions: Mexican Military Police Patrols Versus High-Value Targeted Operations." Armed Forces \& Society, 43(1), pp. 53-71. https://doi.org/10.1177/0095327X16631084.

RIVERA, A. (2014) "Ve CNDH claramente choque en caso Tlatlaya." Sección Primera, 24 de septiembre.

SCJN (1996) Acción de inconstitucionalidad 1/96. Leonel Godoy Rangel y otros, México. Suprema Corte de Justicia de la Nación.

SEDENA, Secretaría de la Defensa Nacional (2014) "Incidente ocurrido en el municipio de Tlatlaya, Estado de México, el 30 de junio de 2014." Comunicado. 19 de septiembre.

SEDENA (2017) Quinto Informe de labores 2016-2017, México: Secretaría de la Defensa Nacional.

Senado de la República (2015) Versión estenográfica de la comparecencia del integrante de la terna para ministro de la Suprema Corte de Justicia de la Nación, Alejandro Jaime Gómez Sánchez, ante la Comisión de Justicia del Senado de la República (tercera y última parte), Coordinación de Comunicación Social, 2 de diciembre.

SIERRA GUZMÁN, J. L. (2007) El enemigo interno. Contrainsurgencia y Fuerzas Armadas en México, México: Plaza y Valdés.

SILVA, C. y PADILLA, S. (2020) “Tortura en la guerra contra el narcotráfico en México: entre la militarización, el control político y el nuevo sistema de justicia penal." Latin American Law Review, 4, pp. 107-128. https://doi.org/10.29263/lar04.2020.05.

SILVA, C. y PADILLA, S. (2019) "Militarización y uso de la fuerza durante y después de la detención sobre la población privada de la libertad en México." Desacatos, 60, pp. 58-77.

SILVA, C., PÉREZ CORREA, C. y GUTIÉRREZ, R. (2017) “Índice de letalidad 2008-2014: menos enfrentamientos, misma letalidad, más opacidad.” Perfiles latinoamericanos, 25(50), pp. 331-359. https://doi.org/10.18504/p12550-0152017.

SILVA, C., PÉREZ CORREA, C. y GUTIÉRREZ, R. (2012) "Uso de la fuerza letal. Muertos, heridos y detenidos en enfrentamientos de las fuerzas federales con presuntos miembros de la delincuencia organizada." Desacatos, 40, pp. 47-64.

SOTOMAYOR, A. (2013) Militarization in Mexico and Its Implications, Calhoun: The NPS Institutional Archive.

STEPAN, A., \& WOLFSON, L. (1988) "Las prerrogativas de los militares en los nuevos regímenes democráticos." Desarrollo Económico, 27(108), pp. 479-504. https:// doi.org/10.2307/3467076. 
STEVENSON, M. (2014) "In Mexico, lopsided death tolls draw suspicion." Associated Press News, July 8.

UN (2016) The Minnesota Protocol on the Investigation of Potentially Unlawful Death, New York/Geneva: Office of the United Nations High Commissioner for Human Rights.

VILALTA, C. (2014) "How Did Things Get So Bad Quickly? An Assessment of the Initial Conditions of the War against Organized Crime in Mexico." European Journal on Criminal Policy and Research, 20(1), pp. 137-161. https://doi.org/10.1007/ s10610-013-9218-2.

ZAFARONI, R. (2006) El crimen de Estado como objeto de la criminología, México: IIJ-UNAM.

ZAVERUCHA, J. (2008) "La militarización de la seguridad pública en Brasil." Nueva Sociedad, 123(1), pp. 128-146. https://doi.org/10.5211/iys.5.article8.

Received: July $22^{\text {nd }} 2020$

Accepted: September $7^{\text {th }} 2020$ 